\title{
Gambaran kematian maternal di RSUP Prof. Dr. R. D. Kandou Manado 1 Januari 2013 - 31 Desember 2015
}

\author{
${ }^{1}$ Mustika S. Lumbanraja \\ ${ }^{2}$ Hermie M. M. Tendean \\ ${ }^{2}$ Maria Loho
}

\author{
${ }^{1}$ Kandidat Skripsi Fakultas Kedokteran Universitas Sam Ratulangi Manado \\ Bagian Obstetri dan Ginekologi Kedokteran Universitas Sam Ratulangi Manado \\ Email: tikalumbanraja@yahoo.co.id
}

\begin{abstract}
Maternal death is the death of a pregnant woman or death within 42 days after the termination of pregnancy, irrespective of the length and location of the pregnancy, caused by anything related to pregnancy, or aggravated by the pregnancy or its handling, but not the death caused by accident or accidentally. Maternal mortality is one of the indicators to evaluate the progress of the health of a country, especially those related to maternal and child health issues. This study was aimed to determine the characteristics of maternal death. This was a descriptive retrospective study using data of the Medical Record Department of Prof. Dr. R. D. Kandou Manado from 1 January 2013 to 31 December 2015. In this study, there were 41 cases of maternal deaths. In 2013 and 2014, the highest death rate was in the age group > 35 years, while in 2015 in the age group 20-25 years. Based on the number of parity, the highest mortality rates in the number of parity 2-3 in 2013 and 2014, while in 2015 the number of parity $\leq 1$. The highest mortality rate by level of education was high school educated. Based on employment status, the highest mortality rate was in the group of working mother. The highest death toll was based on marital status in the group who are married. Based on the status of the referral highest mortality rate was in status is not a referral. This study found that the highest cause of maternal mortality is three consecutive years eclampsia, sepsis, eclampsia. Conclusion: Of 41 cases of maternal deaths in the Department of Prof. Dr. R. D. Kandou Manado for 3 years, the most cause of death was due to eclampsia/pre-eclampsia which was 4-7 cases each year. Maternal mortality rate per 100000 live births yearly in sequence were $373,427,789$.
\end{abstract}

Keywords: maternal death

\begin{abstract}
Abstrak: Kematian maternal adalah kematian wanita yang terjadi saat hamil atau dalam 42 hari setelah berakhirnya kehamilan, tidak tergantung dari lama dan lokasi kehamilan, disebabkan oleh apapun yang berhubungan dengan kehamilan, atau yang diperberat oleh kehamilan tersebut atau penanganannya, tetapi bukan kematian yang disebabkan oleh kecelakaan atau kebetulan. Kematian maternal merupakan salah satu indikator untuk melihat kemajuan kesehatan suatu negara, khususnya yang berkaitan dengan masalah kesehatan ibu dan anak. Penelitian ini bertujuan untuk mengetahui gambaran kematian maternal. Jenis penelitian ini ialah deskriptif retrospektif menggunakan rekam medik di RSUP Prof. Dr. R. D. Kandou Manado periode 1 Januari 2013-31 Desember 2015. Pada penelitian ini, ditemukan 42 kasus kematian maternal. Pada tahun 2013 dan 2014 angka kematian tertinggi di kelompok usia >35 tahun, sedangkan tahun 2015 ditemukan di kelompok usia 20-25 tahun. Berdasarkan jumlah paritas, angka kematian tertinggi pada jumlah paritas 2-3 di tahun 2013 dan 2014, sedangkan untuk tahun 2015 pada jumlah paritas $\leq 1$. Angka kematian tertinggi berdasarkan tingkat pendidikan ialah SMA. Berdasarkan status pekerjaan, angka kematian tertinggi berada pada kelompok ibu yang bekerja. Angka kematian tertinggi berdasarkan status pernikahan berada pada kelompok yang sudah menikah. Berdasarkan status rujukan angka kematian yang tertinggi ialah pada status bukan rujukan. Pada penelitian ini ditemukan penyebab kematian ibu yang tertinggi 3 tahun berurutan ialah pre-eklampsia/eklampsia, infeksi, pre-eklampsia/eklampsia. Simpulan: Jumlah kematian
\end{abstract}


maternal di RSUP Prof. Dr. R. D. Kandou Manado selama 3 tahun yaitu sebanyak 41 kasus. Penyebab kematian terbanyak disebabkan oleh eklampsia/pre-eklampsia yaitu 4-7 kasus per tahun. Angka kematian ibu per 100000 kelahiran hidup per tahun berurutan ialah 373, 427, 789.

Kata kunci: kematian maternal

Kematian maternal adalah kematian wanita yang terjadi saat hamil atau dalam 42 hari setelah berakhirnya kehamilan, tidak tergantung dari lama dan lokasi kehamilan, disebabkan oleh apapun yang berhubungan dengan kehamilan, atau yang diperberat oleh kehamilan tersebut atau penanganannya, tetapi bukan kematian yang disebabkan oleh kecelakaan atau kebetulan. ${ }^{1}$

Faktor penyebab kematian maternal terbesar menurut Depkes RI 2014 periode 2010-2013 adalah perdarahan. Sedangkan partus lama merupakan penyumbang kematian maternal terendah. Sementara itu faktor lain yang menjadi penyebab kematian maternal adalah hipertensi, infeksi, abortus, dan lain-lain. Yang dimaksud dengan penyebab lain-lain adalah penyebab kematian maternal secara tidak langsung, seperti penyakit kanker, ginjal, jantung, tuberkulosis, atau penyakit lain yang diderita $i b u{ }^{2}$

Angka Kematian Ibu (AKI) diperkirakan terjadi 287.700 di seluruh dunia pada tahun 2010. Indonesia memiliki jumlah kematian maternal tertinggi di ASEAN sebesar 307/100.000 kelahiran hidup. ${ }^{3}$ Kasus gawatdarurat obstetri adalah kasus obstetri yang apabila tidak segera ditangani akan berakibat kesakitan yang berat, bahkan kematian ibu, janin, dan bayi baru lahir. Pada umumnya kematian maternal di negara-negara berkembang, berkaitan dengan setidaknya satu dari tiga keterlambatan (The Three Delay Models). ${ }^{4,5}$ Keterlambatan yang pertama adalah keterlambatan dalam mengambil keputusan untuk mencari perawatan kesehatan apabila terjadi komplikasi obstetrik. Keterlambatan kedua terjadi setelah keputusan untuk mencari perawatan kesehatan diambil. Keterlambatan ketiga yaitu keterlambatan dalam memperoleh perawatan di fasilitas kesehatan. $^{6}$
Upaya menurunkan angka kematian maternal Pemerintah merencanakan program Safe Motherhood, yang terdiri dari 4 pilar utama, yaitu; Keluarga berencana, memastikan setiap pasangan mempunyai akses informasi dan pelayanan KB, pelayanan antenatal, untuk mencegah adanya komplikasi obstetri, persalinan yang aman, memastikan semua penolong persalinan mempunyai pengetahuan, keterampilan dan alat untuk memberikan pertolongan yang aman dan bersih, pelayanan obstetri esensial, memastikan pelayanan obstetri untuk risiko tinggi dan berkomplikasi tersedia bagi ibu hamil yang membutuhkannya. ${ }^{1,7}$

\section{METODE PENELITIAN}

Jenis penelitian ini ialah deskriptif retrospektif. Penelitian ini dilakukan di bagian Obstetri Ginekologi RSUP Prof Dr. R. D. Kandou Manado dengan melihat catatan rekam medis pasien pada tanggal 1 Januari 2013 - 31 Desember 2015.

Subjek pada penelitian ini adalah semua kasus kematian maternal di bagian Obstetri Ginekologi di RSUP Prof. Dr. R. D. Kandou Manado periode 1 Januari 2013 -31 Desember 2015. Kriteria Inklusi, semua pasien dengan kematian maternal yang tercatat di RSUP Prof. Dr. R. D. Kandou Manado. Kriteria eksklusi ialah kasus kematian maternal yang death on arrival. Penelitian ini menggunakan data rekam medis yang meliputi paritas, usia ibu, jumlah paritas, pendidikan, pekerjaan, status pernikahan, rujukan, penyebab kematian. Data yang diperoleh disajikan dalam bentuk tabel distribusi.

\section{HASIL PENELITIAN}

Kasus kematian maternal di RSUP Prof. DR. R. D. Kandou Manado periode 1 Januari 2013-31 Desember 2015 berjumlah 41 kasus, Pada Tabel 1 ditemukan angka 
kematian ibu tertinggi tahun 2013 dan 2014 berdasarkan usia berada pada kelompok usia di atas 35 tahun, sedangkan tahun 2015 ditemukan pada kelompok usia 20-25 tahun.

Pada Tabel 2 dapat dilihat angka kematian ibu tertinggi pada tahun 2013 dan 2014 berdasarkan jumlah paritas berada pada jumlah paritas 2-3, sedangkan pada tahun 2015 ditemukan pada jumlah paritas $\leq 1$.

Pada Tabel 3 dapat dilihatangka kematian ibu tertinggi berdasarkan tingkat pendidikan berada pada tingkat pendidikan SMA. Pada Tabel 4 angka kematian ibu tertinggi berdasarkan status pekerjaan berada pada kelompok ibu yang bekerja.

Pada Tabel 5 angka kematian ibu tertinggi berdasarkan status pernikahan berada pada kelompok ibu yang sudah menikah. Pada Tabel 6 berdasarkan status rujukan angka kematian ibu yang tertinggi adalah pada status bukan rujukan.

Pada Tabel 7 penyebab kematian ibu yang tertinggi 3 tahun berurutan adalah pre-eklampsia/ eklampsia, infeksi, preeklampsia/eklampsia. Pada Tabel 8 dapat dilihat angka kematian ibu per 100000 kelahiran hidup berurutan adalah 373,427 , 789.

Tabel 1. Distribusi Kematian Ibu berdasarkan usia

\begin{tabular}{lcccccc}
\hline \multirow{2}{*}{ Kelompok usia } & \multicolumn{2}{c}{$\mathbf{2 0 1 3}$} & \multicolumn{2}{c}{$\mathbf{2 0 1 4}$} & \multicolumn{2}{c}{$\mathbf{2 0 1 5}$} \\
\cline { 2 - 7 } & $\sum$ & $\%$ & $\sum$ & $\%$ & $\sum$ & $\%$ \\
\hline$<20$ & 1 & 7,14 & 0 & 0 & 2 & 15,38 \\
$20-25$ & 2 & 14 & 3 & 21,43 & 4 & 30,77 \\
$26-30$ & 5 & 35,71 & 3 & 21,43 & 1 & 7,69 \\
$31-35$ & 0 & 0 & 3 & 21,43 & 2 & 15,38 \\
$>35$ & 6 & 42,85 & 5 & 35,71 & 3 & 23,08 \\
Tidak ada data & 0 & 0 & 0 & 0 & 1 & 7,69 \\
Total & 14 & 100 & 14 & 100 & 13 & 100 \\
\hline
\end{tabular}

Tabel 2. Distribusi Kematian Ibu berdasarkan Jumlah Paritas

\begin{tabular}{lcccccc}
\hline \multirow{2}{*}{ Jumlah Paritas } & \multicolumn{2}{c}{$\mathbf{2 0 1 3}$} & \multicolumn{2}{c}{$\mathbf{2 0 1 4}$} & \multicolumn{2}{c}{$\mathbf{2 0 1 5}$} \\
\cline { 2 - 7 } & $\sum$ & $\%$ & $\sum$ & $\%$ & $\sum$ & $\%$ \\
\hline$\leq 1$ & 3 & 21,43 & 3 & 21,43 & 7 & 53,85 \\
$2-3$ & 7 & 50,00 & 7 & 50,00 & 3 & 23,08 \\
$\geq 4$ & 1 & 7,14 & 3 & 21,43 & 1 & 7,69 \\
Tidak ada data & 3 & 21,43 & 1 & 7,14 & 2 & 15,38 \\
Total & 14 & 100 & 14 & 100 & 13 & 100 \\
\hline
\end{tabular}

Tabel 3. Distribusi Kematian Ibu berdasarkan Pendidikan

\begin{tabular}{lcccccc}
\hline \multirow{2}{*}{ Pendidikan } & \multicolumn{2}{c}{$\mathbf{2 0 1 3}$} & \multicolumn{2}{c}{$\mathbf{2 0 1 4}$} & \multicolumn{2}{c}{$\mathbf{2 0 1 5}$} \\
\cline { 2 - 7 } & $\sum$ & $\%$ & $\sum$ & $\%$ & $\sum$ & $\%$ \\
\hline SD & 1 & 7,14 & 0 & 0 & 0 & 0 \\
SMP & 1 & 7,14 & 5 & 35,71 & 2 & 15,38 \\
SMA & 11 & 78,57 & 6 & 42,86 & 9 & 69,23 \\
Perguruan Tinggi & 0 & 0 & 1 & 7,14 & 1 & 7,69 \\
Tidak ada data & 1 & 7,14 & 2 & 14,29 & 1 & 7,69 \\
$\quad$ Total & 14 & 100 & 14 & 100 & 13 & 100 \\
\hline
\end{tabular}


Tabel 4. Distribusi Kematian Ibu berdasarkan Status Pekerjaan

\begin{tabular}{lcccccc}
\multirow{2}{*}{ Pekerjaan } & \multicolumn{2}{c}{$\mathbf{2 0 1 3}$} & \multicolumn{2}{c}{$\mathbf{2 0 1 4}$} & \multicolumn{2}{c}{$\mathbf{2 0 1 5}$} \\
\cline { 2 - 7 } & $\sum$ & $\%$ & $\sum$ & $\%$ & $\sum$ & $\%$ \\
\hline Bekerja & 13 & 92,86 & 11 & 78,57 & 10 & 76,92 \\
Tidak bekerja & 0 & 0 & 1 & 7,14 & 2 & 15,38 \\
Tidak ada data & 1 & 7,14 & 2 & 14,29 & 1 & 7,69 \\
$\quad$ Total & 14 & 100 & 14 & 100 & 13 & 100 \\
\hline
\end{tabular}

Tabel 5. Distribusi Kematian Ibu berdasarkan Status Pernikahan

\begin{tabular}{lcccccc}
\hline \multirow{2}{*}{ Status Pernikahan } & \multicolumn{2}{c}{$\mathbf{2 0 1 3}$} & \multicolumn{2}{c}{$\mathbf{2 0 1 4}$} & \multicolumn{2}{c}{$\mathbf{2 0 1 5}$} \\
\cline { 2 - 7 } & $\sum$ & $\%$ & $\sum$ & $\%$ & $\sum$ & $\%$ \\
\hline Menikah & 12 & 85,71 & 11 & 78,57 & 10 & $76 ., 92$ \\
Tidak menikah & 2 & 14,29 & 1 & 7,14 & 2 & 15,38 \\
Tidak ada data & 0 & 0 & 2 & 14,29 & 1 & 7,69 \\
\multicolumn{1}{c}{ Total } & 14 & 100 & 14 & 100 & 13 & 100 \\
\hline
\end{tabular}

Tabel 6. Distribusi Kematian Ibu berdasarkan Rujukan

\begin{tabular}{ccccccc}
\hline \multirow{2}{*}{ Rujukan } & \multicolumn{2}{c}{2013} & \multicolumn{2}{c}{2014} & \multicolumn{2}{c}{2015} \\
\cline { 2 - 7 } & $\sum$ & $\%$ & $\sum$ & $\%$ & $\sum$ & $\%$ \\
\hline Rujukan & 1 & 7,14 & 1 & 7,14 & 5 & 38,46 \\
Bukan rujukan & 13 & 92,86 & 11 & 78,57 & 7 & 53,85 \\
Tidak ada data & 0 & 0 & 2 & 14,29 & 1 & 7,69 \\
Total & 14 & 100 & 14 & 100 & 13 & 100 \\
\hline
\end{tabular}

Tabel 7. Distribusi Kematian Ibu berdasarkan Penyebab Kematian

\begin{tabular}{lcccccc}
\hline \multirow{2}{*}{ Penyebab Kematian } & \multicolumn{2}{c}{$\mathbf{2 0 1 3}$} & \multicolumn{2}{c}{$\mathbf{2 0 1 4}$} & \multicolumn{2}{c}{$\mathbf{2 0 1 5}$} \\
\cline { 2 - 7 } & $\sum$ & $\%$ & $\sum$ & $\%$ & $\sum$ & $\%$ \\
\hline Pre-Eklampsia/ Eklampsia & 5 & 35,71 & 4 & 28,57 & 8 & 61,54 \\
Perdarahan Postpartum / & 3 & 21,43 & 2 & 14 & 2 & 15,38 \\
Antepartum & 5 & 35,71 & 6 & 42,86 & 1 & 7,69 \\
Infeksi & 0 & 0 & 2 & 14,29 & 0 & 0 \\
Gagal Napas & 0 & 0 & 0 & 0 & 1 & 7,69 \\
Congetive Heart Failure & 1 & 7,14 & 0 & 0 & 0 & 0 \\
Tuberkulosis & 0 & 0 & 0 & 0 & 1 & 7,69 \\
Tidak ada data & 14 & 100 & 14 & 100 & 13 & 100 \\
Total & & & & & & \\
\hline
\end{tabular}

Tabel 8. Kematian Ibu per Tahun

\begin{tabular}{cccc}
\hline \multirow{2}{*}{ Tahun } & \multicolumn{2}{c}{$\sum$} & \multirow{2}{*}{$\%$} \\
\cline { 2 - 3 } & $\begin{array}{c}\text { Kelahiran } \\
\text { Hidup }\end{array}$ & Kematian Ibu & \\
\hline 2013 & 3750 & 14 & 373 \\
2014 & 3276 & 14 & 427 \\
2015 & 1647 & 13 & 789 \\
\hline
\end{tabular}

\section{BAHASAN}

Penelitian dilakukan berdasarkan data yang telah dikumpulkan selama 3 tahun terakhir yaitu mulai tahun 2013 sampai tahun 2015 di RSUP Prof. Dr. R.D. Kandou Manado. Faktor-faktor yang diteliti pada penelitian ini antara lain umur, tingkat pendidikan, pekerjaan, jumlah paritas, status pernikahan, status rujukan dan penyebab kematian.

Umur ibu pada saat melahirkan mempengaruhi kematian ibu..Pada tahun 2013 dan 2014 angka kematian ibu tertinggi terjadi pada kelompok umur diatas 
35 tahun dengan persentase $42,86 \%$ dan $35,71 \%$. Namun pada tahun 2015 angka kematian ibu tertinggi menurun pada kelompok umur 20-25 tahun yaitu 30,77\%. Wanita yang hamil pada umur kurang dari 20 tahun, organ-organ reproduksi belum berfungsi dengan sempurna, sehingga bila terjadi kehamilan dan persalinan akan lebih mudah mengalami komplikasi, sedangkan wanita berumur diatas 35 tahun lebih meningkat risikonya dalam masalahmasalah seperti tekanan darah tinggi, diabetes gestasional (diabetes yang berkembang selama kehamilan) dan komplikasi selama persalinan. ${ }^{8}$

Berdasarkan jumlah paritas, ditemukan kematian ibu tertinggi pada tahun 2013 dan 2014 terjadi pada kelompok paritas 2-3 (50,00\%). Sedangkan ditahun 2015 ditemukan angka tertinggi terdapat dikelompok kurang dari atau sama dengan 1 yaitu $(53,85 \%)$. Hasil ini sesuai dengan penelitian yang dilakukan Zein $\mathrm{F}$, dimana ibu yang meninggal terbanyak adalah paritas $1 .^{9}$

Semakin tinggi tingkat pendidikan maka semakin rendah risiko mengalami kematian maternal. ${ }^{9}$ Teori tersebut berbanding terbalik dengan hasil yang didapatkan pada tabel 3, dimana angka kematian ibu berdasarkan tingkat pendidikan paling tinggi pada wanita dengan tingkat pendidikan SMA, yaitu pada tahun 2013 sebanyak 11 orang (78,57\%), pada tahun 2014 sebanyak 6 orang $(42,86 \%)$ dan pada tahun 2015 mencapai 9 orang $(69,23)$. Sedangkan tingkat pendidikan yang paling rendah adalah SD yaitu sebanyak 1 orang $(7,14 \%)$.

Ibu hamil yang bekerja rentan terkena penyakit karena selama bekerja tidak memperhatikan asupan nutrisinya, serta juga dapat menyebabkan kelelahan dan stres. ${ }^{8}$ Berdasarkan status pekerjaan angka kematian ibu tertinggi terjadi pada wanita bekerja yaitu pada tahun 2013 mencapai $92,86 \%$, tahun 2014 mencapai $78,57 \%$ dan pada tahun 2015 mencapai 76,92\%.

Pada penelitian ini juga ditemukan kematian ibu tertinggi dengan status pernikahan menikah yakni secara berurutan
12 orang $(85,71 \%), 11$ orang $(78,57 \%), 10$ orang $(76,92 \%)$. Hasil ini sesuai dengan penelitian yang dilakukan oleh Mattarungan S, dimana angka kematian ibu tertinggi terjadi pada status ibu yang menikah. $^{3}$

Pasien yang dirujuk berarti fasilitas kesehatan dan tenaga kesehatan tempat pasien dirawat sebelumnya kurang memadai. ${ }^{3}$ Berdasarkan status rujukan subjek penelitian angka kematin ibu tertinggi terjadi pada status bukan rujukan yakni pada tahun 2013 mencapai 92,86\%, tahun 2014 mencapai 78,57\%, dan pada tahun 2015 mencapai 53,85\%. Hasil ini sesuai dengan penelitian yang dilakukan oleh Fibriana AI dimana ditemukan kasus kematian maternal terbanyak berada di rumah sakit. Keadaan ini menunjukkan bahwa kemungkinan ibu-ibu tersebut meninggal dalam kondisi kesehatan yang sudah kurang baik sebelum dibawa ke rumah sakit atau dapat juga disebabkan oleh keterlambatan merujuk dan keterlambatan penanganan ditempat rujukan. ${ }^{10}$

Penyebab utama kematian ibu tahun 2013 didominasi oleh pre-eklampsia/ eklampsia dan infeksi yaitu ditemukan $35,71 \%$, pada tahun 2014 ditemukan sebanyak 42,86\% kasus kematian maternal disebakan oleh infeksi, sedangkan tahun 2015 ditemukan 61,54 kasus kematian maternal disebabkan oleh pre-eklampsia/ eklampsia. Penyebab kematian maternal yang ditemukan adalah perdarahan, gagal napas, congestive heart failure, tuberkulosis. Hal ini tidak sejalan dengan faktor penyebab kematian maternal terbesar menurut Depkes RI 2014 periode 20102013 yaitu perdarahan., ${ }^{2,9}$

Angka kematian ibu per 100000 kelahiran hidup yaitu tahun 2013 didapat 373, tahun 2014 didapat 427, dan 2015 didapat 789. Angka kematian ibu meningkat drastis disebabkan karena menurunnya jumlah persalinan dengan kelahiran hidup yang ada di rumah sakit, berhubung karena RSUP Prof. Dr. R. D. Kandou Manado sudah menjadi rumah sakit tipe A yang tidak menerima kelahiran spontan. 


\section{SIMPULAN}

Jumlah kematian maternal di RSUP Prof. Dr. R. D. Kandou Manado selama 3 tahun yaitu sebanyak 41 kasus. Penyebab kematian terbanyak disebabkan oleh eklampsia/pre-eklampsia yaitu 4-7 kasus kematian maternal tiap tahunnya.

\section{SARAN}

Perlu meningkatkan pengetahuan mengenai kejadian kematian maternal, mengupayakan tercapainya fasilitas kesehatan dan tenaga medis yang memadai sampai ditingkat daerah, dan memperbaiki sistem penyimpanan data rumah sakit agar memudahkan peneliti selanjutnya.

\section{DAFTAR PUSTAKA}

1. WHO. Maternal mortality in 2000. Department of Reproductive Health and Research WHO,2003.

2. Depkes RI. Situasi kesehatan ibu. Direktorat Kesehatan Ibu. Jakarta. 2014:h. 2-3

3. Noita L, Sulamah M, Sutiko. Permodelan Maternal Mortality di Jawa Timur Dengan Pendekatan Geographically Wighted Poisson Regression (GWPR). 2013:h.1-2

4. Tim Kajian AKI-AKA, Depkes RI. Kajian kematian ibu dan anak di Indonesia.
Badan Penelitian dan Pengembangan Kesehatan, Jakarta; Depkes R.I, 2004.

5. Rachimhadhi T. Prinsip dasar penanganan kegawatdaruratan. In: Ilmu Kebidanan (4th ed). Jakarta: Bina Pustaka, 2010; p. 391-400.

6. UNFPA. Maternal mortality update 2002, a focus on emergency obstetric care. New York, UNFPA; 2003.

7. Saifudin AB, dkk. Buku acuan nasional pelayanan kesehatan maternal dan neonatal. Jakarta: Yayasan Bina Pustaka Sarwono Prawirohardjo, 2000.

8. Harun HM, Abdullah AZ, Ansariadi. Hubungan karakteristik dan perilaku ibu dengan status persalinan di wilayah pesisir Kecamatan Tallo [Skripsi]. Makasar: Universitas Hasanuddin; 2014.

9. Zein F, Budiman, Yulianto FA. Hubungan Tingkat Pendidikan dan Jumlah Paritas Dengan Kematian Ibu di Kabupaten Bandung Tahun 2014. Bandung: Universitas Islam Bandung; 2015.

10. Fibriana AI. Faktor-faktor risiko yang mempengaruhi kematian maternal (studi kasus di kabupaten Cilacap). Semarang: Universitas Diponegoro; 2007 